\title{
NEW BIOSTRATIGRAPHICAL FINDINGS ON THE PADEHA FORMATION BASED ON CONODONT ACCUMULATION IN YAZDANSHAHR, KERMAN, CENTRAL IRAN
}

\author{
NASEHI, E. \\ Department of Geology, Faculty of Science, Islamic Azad University, Natanz Branch \\ Natanz, Iran \\ e-mail:nasehehsan@gmail.com
}

(Received $9^{\text {th }}$ Jun 2017; accepted $27^{\text {th }}$ Oct 2017)

\begin{abstract}
The aim of the study was the biostratigraphical evaluation of Padeha Formation based on conodont accumulation in Yazdanshahr. The section under study is located north of Yazdanshahr in northwestern Zarand County in Kerman, central Iran. After investigating several sections of the Padeha formation in the Kerman area, one fossiliferous section was chosen for study. In terms of lithology, the section is composed mainly of red-colored clastic and evaporative rock with carbonate intercalations. The conodont accumulations indicate two local biozones: the Zieglerodina remscheidensis and Pandorinellina steinhornensis assemblage zones and the Eugenathodontidae-Icriodus assemblage zone. Based on the abundance of Spathognathodontidae and similarities to global biozones, these biozones were found to be of the Late Silurian (Early Pridoli) age. No evidence of the Icriodus genus (especially woschmidti or postwoschmidti species) was observed in this assemblage. The latter biozones manifest the appearance of Eugenathodontidae in the Early Devonian; therefore, a sedimentary hiatus exists within the Late Silurian to the start of Early Devonian (Late Pridoli to Pragian). The sediment was deposited in a depositional environment ranging from lagoons to shallow waters (inner carbonate platform). The Yazdanshahr section was the most complete of the Padeha formation because conodonts were found in the lower, middle and upper parts of the section. This function will allow researchers to correlate their sections with these findings based on stratigraphic principles.
\end{abstract}

Keywords: Icriodus, sedimentary environment, Silurian, Kerman, biozones

\section{Introduction}

Devonian deposits in Iran were first reported on a geological map prepared by the National Iranian Oil Company. Located near Gush-Kamar in the Ozbak-Kuh mountains, the type section was studied by Ruttner et al. (1968), Stocklin (1971) and Stocklin et al. (1965, 1991). Late Silurian-Early Devonian sediment has been studied in Kerman province in Iran and reported according to stratigraphic principles (Huckriede et al., 1962). Most recent studies have been based on conodonts, fish remnants, brachiopods, corals and palynomorphs. The following authors have recently worked on conodonts: Ahmadi et al., 2012; Bahrami, 2011, 2013, 2014, 2015; Boncheva et al., 2007; Adhamian, 2003; Ashuri, 2004, 2006; Gholamalian, 2007; Gholamalian and Kebriaei, 2008; Gholamalian et al., 2009; Yazdi, 1999; Weddige, 1984.

Geologically speaking, Iran is divided into five structural units: the Zagros, Alborz, Sanandaj-Sirjan, Eastern Iran and Central Iran (Stocklin et al., 1965; Stocklin, 1968; Stocklin and Nabavi, 1971; Stocklin and Setudehnia, 1991; Heydari et al., 2008). In terms of structure, Central Iran is composed of five blocks: the Lut, Tabas, Kalmard, Posht-Badam, Anar and Dehshir (Alavi, 1991; Heydari et al., 2008; Fig. 1). Devonian sediment has been described in the Jeirud Formation in the Central Alborz (Assereto, 1963), the Khoshyeilagh formation in the northeastern Alborz (Bozorgnia, 1973), the Moli and Ilanqareh Formation (unofficial name) in West Azerbaijan and Maku (western 
Alborz) (Alavi-Naini and Bolourchi, 1973) and the Pedeha, Sibzar, Bahram and Shisto formations in Central Iran (Ruttner et al., 1968).

The type section of the Padeha formation is named after the village of Padeha in the Ozbak-Kuh mountains (Eastern Iran). Lithologically characterized by red sandstone, dolomite and gypsum at Ozbak-Kuh (eastern Central Iran), the Padeha formation overlies the fossiliferous carbonates of the Niur formation and underlies the Sibzar dolomites. This formation formed in the Early Devonian and exhibits shallow facies related to the Caledonian orogeny (Ruttner et al., 1968; Stocklin, 1971). The Padeha formation was deposited in an inner platform and extends across all of the Central Iran basin. Based on its stratigraphic position, this formation has been aged back to the Early Devonian.

Devonian deposits in Iran (Pedeha, Sibzar, etc.) are not well known and a large deal of uncertainty is associated with them. In general, Early Paleozoic Devonian deposits in Iran precipitated in separate geological units. Few studies have been done on the effect of sea level at the time the Late Silurian and Early Devonian rock formed. Evidence indicates the effect of Caledonian movement (Ruttner et al., 1968; Stocklin, 1971). Sea transgression covered most of Iran in the Middle and Late Devonian. In the present research, an attempt is made to determine the age of the sediment based on conodont accumulation.

\section{Methodology and study area}

The structural units of Iran were investigated and the Kalmard block was selected for study. The study area is located about $18 \mathrm{~km}$ from Zarand and $70 \mathrm{~km}$ to the northeast of Kerman. The measured section was delimited as $31^{\circ} 3^{\prime} 55^{\prime \prime} \mathrm{N}$ and $30^{\circ} 2^{\prime} 40^{\prime \prime} \mathrm{N}$ latitude and $56^{\circ} 17^{\prime} 5^{\prime \prime} \mathrm{E}$ and $56^{\circ} 15^{\prime} 10^{\prime \prime} \mathrm{E}$ longitude (Fig. 1).

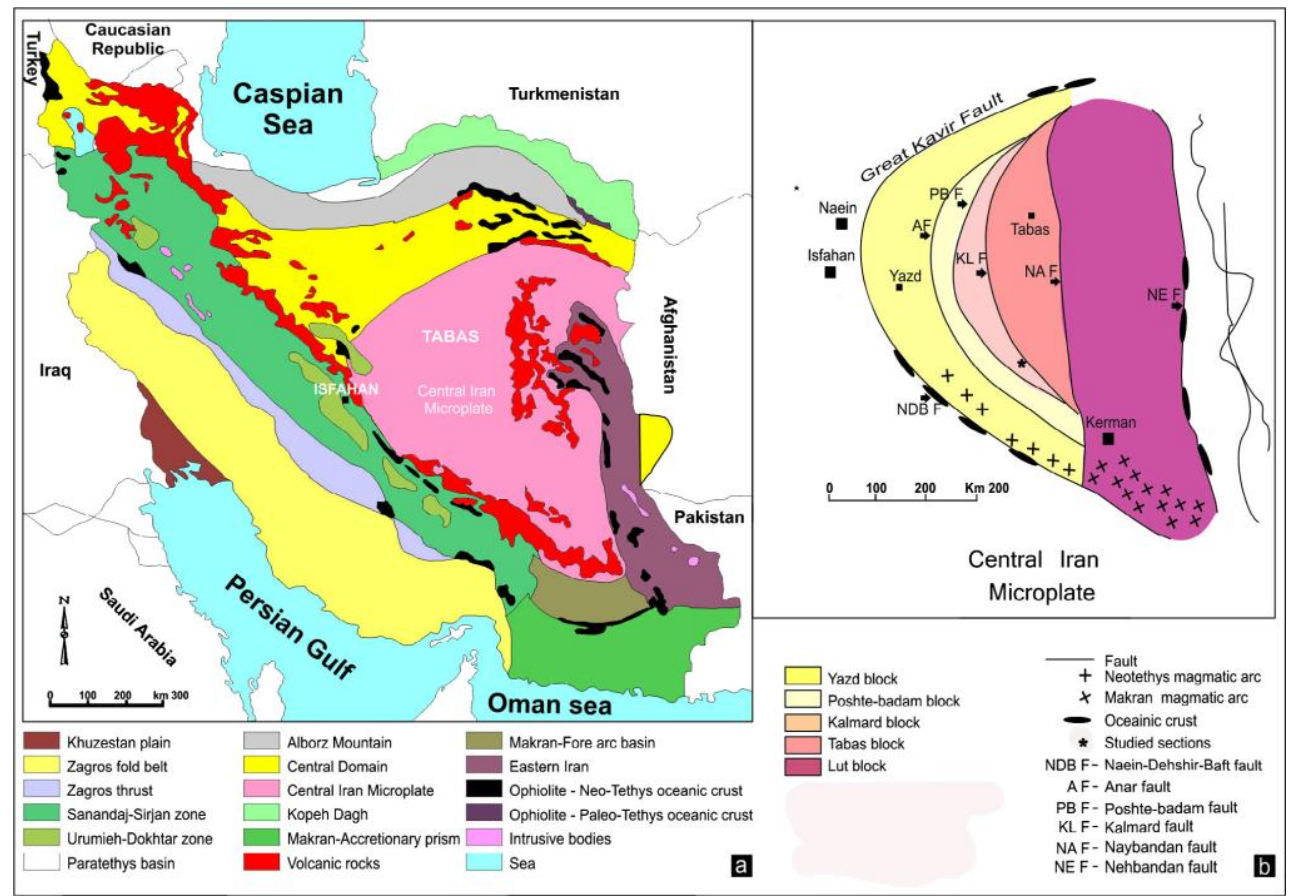

Figure 1. Structural units of Iran located in the studied section 
Field sampling and length measurements were undertaken systematically wherever a change in the lithology was identified to carefully investigate the biostratigraphy of the study area. If needed, more than one sample $(+4 \mathrm{~kg})$ was taken from the corresponding bedding. The samples were studied carefully after undergoing the following preparation steps: crushing (to dimensions of $3 \mathrm{~cm}$ ), acid treatment (10\% acetic acid), washing, sieving $(75,125,250$ and 710 mesh), picking (with a needle) and photography.

\section{Discussion}

An investigation on Late Silurian and Devonian deposits (Padeha, Sibzar, and Bahram) in the Central Iran microplate indicates that, during the Late Silurian, most of Central Iran was exposed out of water. The Devonian deposits in Central Iran formed in separate basins. Evidence indicates a radical variation in thickness even at short distances. For instance, the Hur section is $280 \mathrm{~m}$ thick (Ahmadi et al., 2012), the Varkamar section is $210 \mathrm{~m}$ thick and the Neqeleh section is about $200 \mathrm{~m}$ thick. The Nachf section is about $120 \mathrm{~m}$ thick and the Shomal-Tar section is about $200 \mathrm{~m}$ (near Isfahan) (Bahrami et al., 2015). The Shahmirzad section is $450 \mathrm{~m}$ thick (Heydari et al., 2008) and the Soh section is $88 \mathrm{~m}$ thick (Adhamian, 2003).

These radical changes in thickness can be attributed to horst and graben basins from the Caledonian and Hercynian epirogenic phases in Central Iran (Soffel and Forster, 1980; Weddige, 1984). The presence of gypsum as evaporative facies in the section base along with carbonate intercalations containing Spathognathodontidae indicate a lagoon on an inner carbonate platform (Table 1) (Sweet, 1988; Flugel, 2010). The presence of evaporative facies in the Late Silurian can be attributed to the Ardenian orogeny. The Early Devonian red-colored clastic facies with carbonate intercalations can be attributed to the Earian orogeny.

\section{Lithostratigraphy of Yazdanshahr section}

The study area is located in the northern Shabjereh mountains near Khorramabad (northeastern Kerman, Central Iran; Fig. 2). The local sedimentary rock were different types of clastic, colloidal carbonate and evaporative rock. The lower boundary is covered by alluvial deposits. The two local members were identified as follows:

Lower boundary (base): talus and fluvial (covered)

Member I

Lithozone I

1. $20 \mathrm{~m}$ of grey, reddish and white gypsum with clay or gypsum-bearing clay intercalations.

2. $\quad 6.8 \mathrm{~m}$ of olive green lime and the fresh grayish green colour (argillaceous micrite or sandy mudstone becoming pelmicrite or wackestone in the upper layers).

3. $58 \mathrm{~m}$ of white to red gypsum with grey-coloured shaley limestone intercalations.

4. $32.8 \mathrm{~m}$ of brick-coloured sandstone in alternation with limestone in fresh red color with layering thickness of $0.5-1 \mathrm{~m}$. The penetration of ferrous compounds into the rocks caused their red appearance (sample 3 ).

5. $4.5 \mathrm{~m}$ of light grey and creamy light-grey limestone. This limestone encompasses gypsum beddings in the form of two 1-m thick hard beddings (sample 5). 
Table 1. Distribution of conodont species in Yazdanshahr column

\begin{tabular}{|c|c|c|c|c|c|c|c|c|c|c|c|c|c|c|c|c|c|c|c|c|c|c|c|c|c|c|c|c|}
\hline Yazdan shahr & & & & & & & & & & & & & & & & & & & & & & & & & & & & \\
\hline Taxa & 18 & 19 & 20 & 21 & 22 & 23 & 24 & 25 & 40 & 42 & 49 & 50 & 51 & 53 & 61 & 62 & 67 & 69 & 70 & 73 & 74 & 76 & 80 & 89 & 90 & 91 & \#\#\# & Total \\
\hline Bipennatus Philip, 1965 & & & & & & & & & 3 & 4 & 2 & 3 & 2 & 3 & 1 & 3 & 2 & 1 & 2 & 3 & & & & & & & & 29 \\
\hline Bipennatus bipennatus Bischoff and Ziegler, 1957 & & & & & & & & & & 2 & & & & & & & & 3 & 21 & 2 & & & & & & & & 28 \\
\hline B.bipennatus bipennatus Bischoff and Ziegler, 1957 & & & & & & & & & & & & & & & & & & & & & & & & & & & & 0 \\
\hline Distomodus sp.Branson and Mehl 1947 & & 1 & 1 & & & & & & & & & & & & & & & & & & & & & & & & & 2 \\
\hline Hindeodlla compressa Huddle, 1934 & & & & & & & & & 1 & & & & & & & & & & & & & 1 & & & & & 1 & 3 \\
\hline Hindeodella equidentata Rhodes, 1953 & & & & & & & & 2 & & & & & & & & & & & & & & & & & & & & 2 \\
\hline Icriodus sp Branson and Mehl 1934 & & & & & & & & & 2 & 4 & & & & & & & & & & & & 5 & 1 & & & & & 12 \\
\hline Icriodus brevis, Stauffer, 1940 & & & & & & & & & 2 & & 2 & & & & & & & & & & & & & 2 & 1 & & & 7 \\
\hline Icriodus brevis brevis Stauffer, 1940 & & & & & & & & & & & & & & & & & & & & & & & & & 1 & & & 1 \\
\hline I. brevis spicatus Youngquist and Pelerson, 1947 & & & & & & & & & & & & & & & & & & & & & & & & 3 & 1 & & & 4 \\
\hline Icriodus.regularicresens Bultynck, 1970 & & & & & & & & & & 1 & & & & & & & & & & & 2 & 1 & 1 & 2 & & & & 7 \\
\hline I. struvei Weddig, 1977 & & & & & & & & & & & & & & & & & & & & & 2 & 1 & & & & & & 3 \\
\hline Ligonodina Ulrich and Bassler 1926 & & & 1 & & 2 & 2 & 2 & 1 & & & & & & & & & & & & & & & & & & & & 8 \\
\hline Ligonodina elegans Walliser 1964 & & & & & & & & & & & & & & & & & & & & & & & & & & & & 0 \\
\hline Lonchodina Bassler, 1925 & & 1 & 3 & 1 & 4 & 6 & 6 & 1 & & & & & & & & & & & & & & & & & & & & 22 \\
\hline Neopripniodus Rhodes and Muller, 1956 & & 1 & 1 & 2 & 1 & 2 & 3 & 5 & & & & & & & & & & & & & & & & & & & & 15 \\
\hline Neopripniodus bicurvatus Branson and Mehl, 1933 & & 1 & 3 & 2 & 2 & 1 & & & & & & & & & & & & & & & & & & & & & & 9 \\
\hline Ozarkodina Branson and Mehl, 1933 & & 2 & 3 & 4 & 4 & 3 & 2 & & & & & & & & & & & & & & & & & & & & & 18 \\
\hline Ozarkodina confluens Branson and Mehl, 1933 & & 2 & 6 & 5 & 4 & 2 & 1 & & & & & & & & & & & & & & & & & & & & & 20 \\
\hline Ozarkodina denckmanni Ziegler, 1956 & & 2 & 1 & & 2 & 1 & & & & & & & & & & & & & & & & & & & & & & 6 \\
\hline Ozarkodina media Walliser, 1957 & & & & 1 & & & & & & & & & & & & & & & & & & & & & & & & 1 \\
\hline Ozarkodina typical Branson and Mehl, 1933 & & & 4 & 4 & 3 & 3 & 1 & & & & & & & & & & & & & & & & & & & & & 15 \\
\hline Ozarkodina Ziegleri Walliser, 1964 & & 1 & 2 & 3 & 3 & & 1 & & & & & & & & & & & & & & & & & & & & & 10 \\
\hline Panderodus simplex Branson and Mehl, 1933 & & 1 & 2 & 2 & & & & & & & & & & & & & & & & & & & & & & & & 5 \\
\hline Pandorinellina exigua Philip, 1966 & & 3 & 5 & 6 & 5 & 4 & 2 & & & & & & & & & & & & & & & & & & & & & 25 \\
\hline Pandorinellina steinhornensis Ziegler, 1956 & & 2 & 1 & 5 & 4 & 4 & 2 & & & & & & & & & & & & & & & & & & & & & 18 \\
\hline Plectospathodus Branson and Mehl, 1933 & & 2 & 3 & 3 & 1 & & & & & & & & & & & & & & & & & & & & & & & 9 \\
\hline Trichonodella symetrica Branson and Mehl, 1933 & & 1 & 3 & 4 & 6 & 5 & 2 & & & & & & & & & & & & & & & & & & & & & 21 \\
\hline Wurmiella excavata Branson and Mehl, 1933 & & & 1 & 2 & 2 & & & & & & & & & & & & & & & & & & & & & & & 5 \\
\hline Zieglerodina remscheidensis Ziegler, 1960 & & 2 & 5 & 3 & 6 & 4 & 1 & & & & & & & & & & & & & & & & & & & & & 21 \\
\hline Total & & 22 & 45 & 47 & 49 & 37 & 23 & 9 & 8 & 11 & 4 & 3 & 2 & 3 & 1 & 3 & 2 & 4 & 23 & 5 & 4 & 8 & 2 & 7 & 3 & 0 & 1 & \#\#\# \\
\hline
\end{tabular}

APPLIED ECOLOGY AND ENVIRONMENTAL RESEARCH 16(2):993-1018.

http://www.aloki.hu • ISSN 15891623 (Print) • ISSN 17850037 (Online)

DOI: http://dx.doi.org/10.15666/aeer/1602 9931018

(c) 2018, ALÖKI Kft., Budapest, Hungary 


\section{Yazdanshahr}

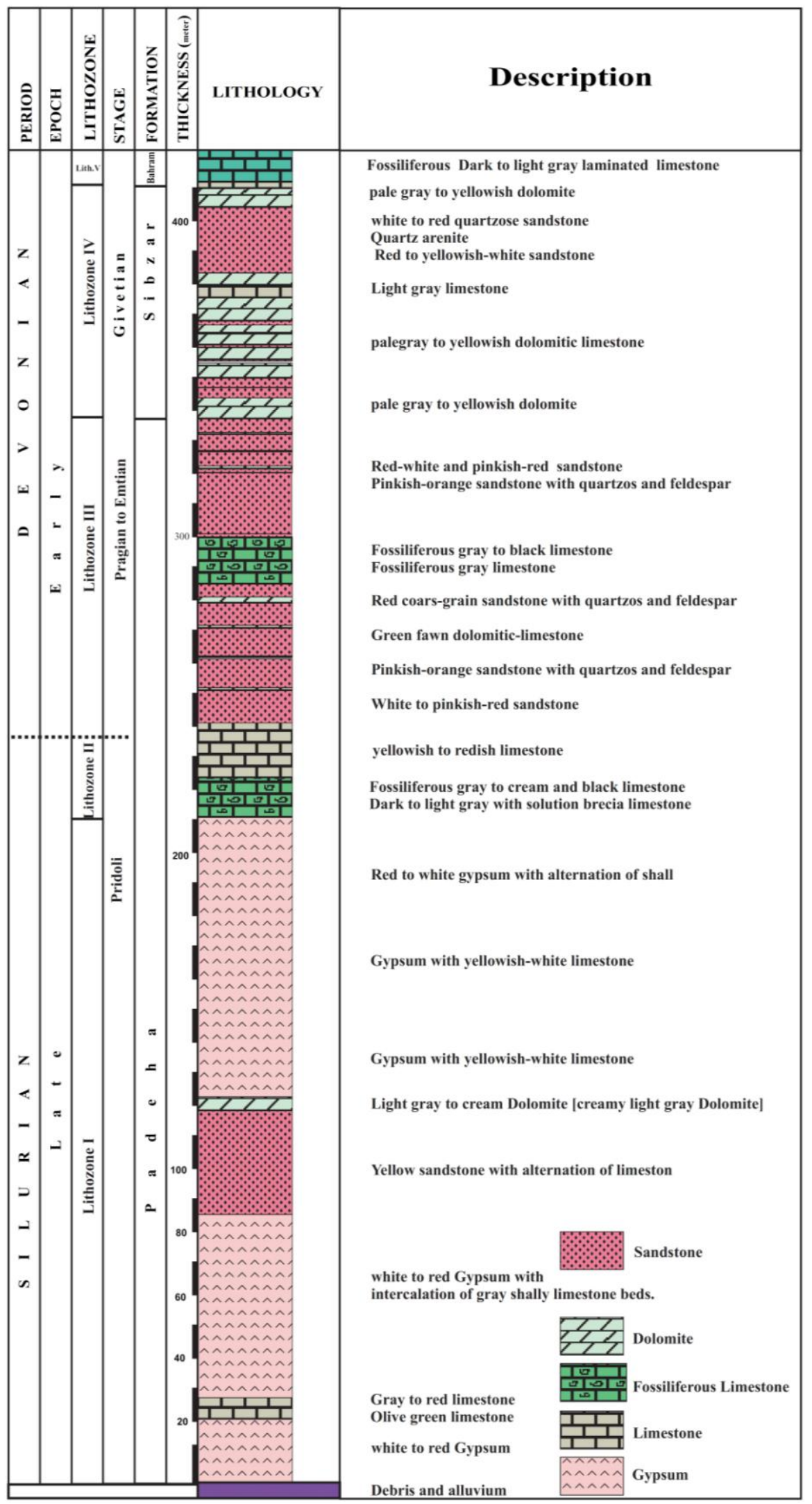

Figure 2. Lithostratigraphic section of Yadanshahr, Iran

APPLIED ECOLOGY AND ENVIRONMENTAL RESEARCH 16(2):993-1018.

http://www.aloki.hu • ISSN 15891623 (Print) • ISSN 17850037 (Online)

DOI: http://dx.doi.org/10.15666/aeer/1602_9931018

(c) 2018, ALÖKI Kft., Budapest, Hungary 
6. $88.4 \mathrm{~m}$ of soft gypsum with thinly-bedded intercalations of pease-coloured limestone.

Lithozone II

7. $13 \mathrm{~m}$ of light- to dark-grey limestone together with shell fragments (sandy bioclast lime wackestone/pelbioclast lime wackestone or sandy biomicrite/pelbiomicrite (light- to dark-grey limestone)). Solution breccia from the dissolution of gypsum can be observed in the base of this rock unit. The identified conodonts include:

a. Ozarkodina confluens (Branson and Mehl, 1933)

b. Spatognathodus primus (Branson and Mehl, 1933)

c. Pandorinellina steinhornensis (Ziegler, 1956)

d. O. confluens (Branson and Mehl, 1933)

e. P. exigua (Philip, 1966)

f. Zieglerodina remscheidensis (Ziegler, 1960)

g. Distomodus (Branson and Mehl, 1947)

h. Hindeodella equidentata (Rhodes, 1953)

i. Ligonodina (Ulrich and Bassler, 1926)

j. L. elegans (Walliser, 1964)

k. Lonchodina (Bassler, 1925)

1. Neopripniodus bicurvatus (Branson and Mehl, 1933)

m. O. denckmanni (Ziegler, 1956)

n. O. ziegleri (Walliser, 1964)

o. Panderodus simplex (Branson and Mehl, 1933)

p. Trichonodella symetrica (Branson and Mehl, 1933)

8. $17.4 \mathrm{~m}$ of yellow to grey limestone, creamy with no fossil which gradually turns to red.

Member II

Lithozone III

9. $10.2 \mathrm{~m}$ of red-white-brick-coloured sandstone containing siliceous cement with quartz and feldspar.

10. $1 \mathrm{~m}$ of thinly-bedded red to white dolomitic sandy limestone (dolograinstone or sandy dolosparite).

11. $10 \mathrm{~m}$ of red sandstone with siliceous cement and abundant quartz and feldspar grains. It turns gradually to micrite and microsparite. The identified conodonts include:

a. I. struvie (Weddige, 1977)

b. I. regularicresens (Bultynck, 1970)

c. I. brevis (Staulfer, 1940)

d. I. brivis spicatus (Youngquist and Peterson, 1947)

e. Bipennatus bipennatus (Bischoff and Ziegler, 1957)

12. $8.7 \mathrm{~m}$ of thinly bedded clay-bearing red sandstone containing trace fossils.

13. $1 \mathrm{~m}$ of gray marl limestone (micrite to microcrystalline matrix, laterally becoming bioclastic lime wackestone or biomicrite)

14. $7 \mathrm{~m}$ of coarse-grained red lime sandstone with weak carbonate cement and abundant clastic grains of quartz and feldspar

15. $2 \mathrm{~m}$ of light green dolomitic limestone (packstone-dolosparite) with sparicalcite cement and abundant rhombohedral calcite 
16. $4 \mathrm{~m}$ of red to white sandstone with medium to coarse grains of quartz and feldspar and siliceous cement

Lithozone IV (Sibzar formation)

17. $15 \mathrm{~m}$ of grey to dark limestone to dolostone with sparicalcite cement and abundant rhombohedra of dolomite. Organic remnants of crinoid debris, fish teeth and conodonts are as follows:

a. I. brevis (Stauffer, 1940)

b. B. bipennatus sub sp.

18. $20.2 \mathrm{~m}$ of red sandstone (quartz arenite), medium- to coarse-grained quartz along with nodules of iron oxide (opaque minerals, feldspar and siliceous cement)

19. $0.2 \mathrm{~m}$ of dark gray limestone (biosparite-grainstone) with sparicalsite cement and calcite rhombohedra. The only conodont is Ozarkodina sp.

20. $17 \mathrm{~m}$ of red sand with argillaceous matrix together with three light-grey dolostone beddings

21. $6.7 \mathrm{~m}$ of yellowish grey dolostone (dolograinstone-dolosparite). The identified conodonts include:

a. Icriodus sp., I. struvei (Weddige, 1977)

b. I. brevis (Stauffer, 1940)

c. I. brevis brevis (Stauffer, 1940)

d. Bipennatus sp., B. bipennatus (Bischol and Ziegler, 1957)

e. Ozarkodina sp.

22. $4.5 \mathrm{~m}$ of white to red quartzose sandstone

23. $20.4 \mathrm{~m}$ of light-grey to yellow dolomite (dolosparite dolograinstone) with three layers of red sandstone.

24. $8 \mathrm{~m}$ of light grey to yellow dolostone with quartzose grains and sparit calcite cement. Identified conodonts include:

a. Icriodus sp., I. aff. regularicresens (Bultynck, 1970)

b. Bippenatus sp 2.

25. $20.63 \mathrm{~m}$ of white to red quartzose sandstone

26. $6 \mathrm{~m}$ of light-gray dolomite (dolograinstone dolosparite)

27. $2 \mathrm{~m}$ of marl containing trilobite, ostracoda, Ecinid spine and bryozoan

Bahram grey brachiopoda limestone (Bahram Formation)

\section{Biozonation of Yazdanshahr section}

The conodont collections in this section contain 15 genus, 20 species and 5 subspecies were identified (Fig. 3). Together, these identify two biozones as follows:

1. Zieglerodina remscheidensis, Pandorinellina steinhornensis assemblage zone.

The elements collected in this part relate to Spathognathodontidae and include the following:

- O. confluence (Branson and Mehl, 1933) (Spathognathodus primus; Branson and Mehl, 1933)

- Zieglerodina remscheidensis (Ziegler, 1960) (S. remscheidensis; Ziegler,1960)

- Pandorinellina steinhornensis (Ziegler, 1966) (S. steinhornensis, Ziegler, 1956)

- P. exiguus philipi (Klapper, 1969) 


\section{Yazdanshahr}

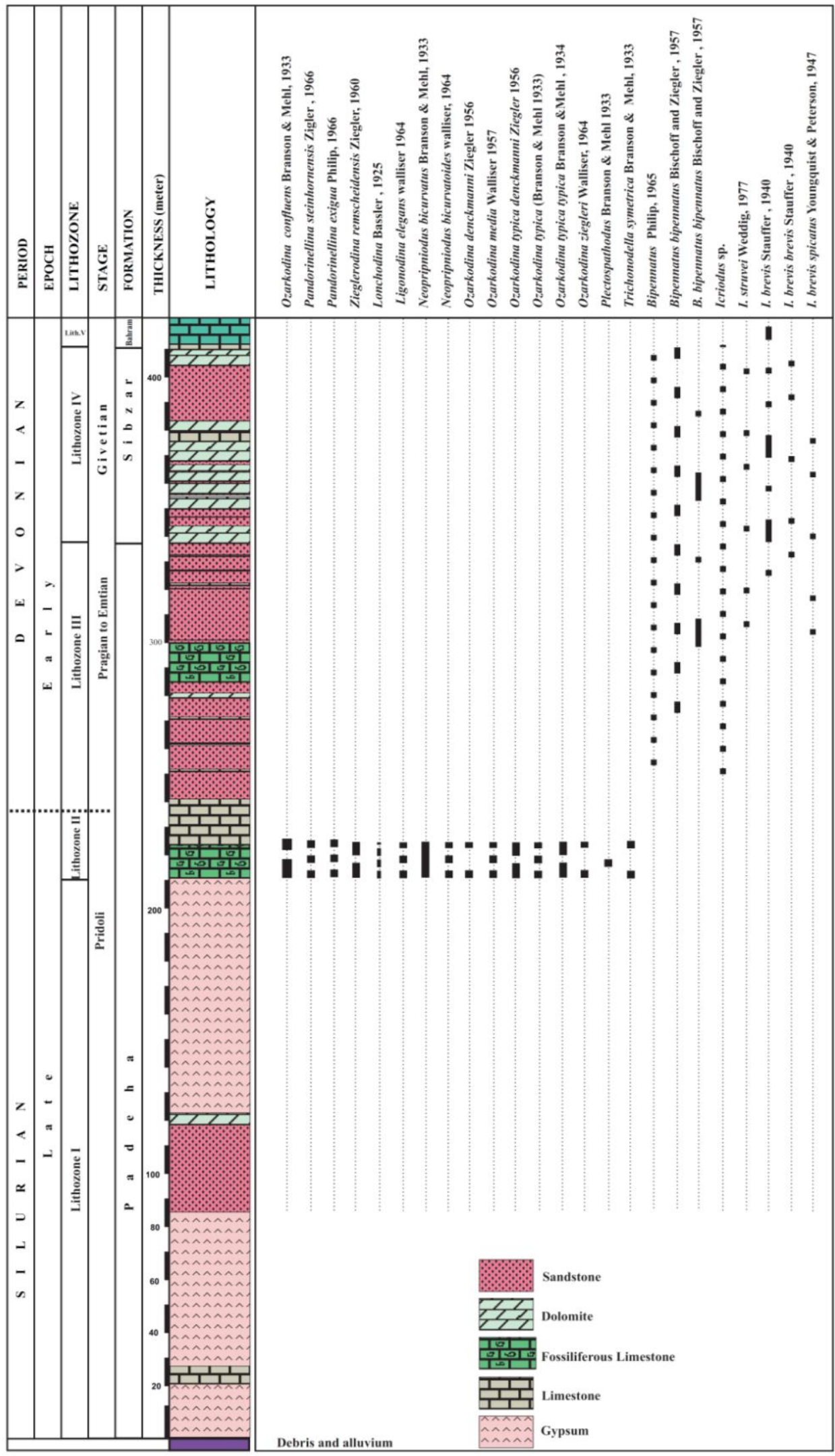

Figure 3. Biostratigraphic section of Yadanshahr, Iran 
The collected elements were comparable to the following:

- Murphy et al. (2004) (from Nevada, Spain, Germany and Czech Republic)

- Farrel (2004) (from Camelford limestone, Australia)

- Corradini et al. (2014) (from Cellon section)

- Corriga et al. (2011) (from Malinfier section, Italy)

- Mathieson et al. (2016) (from Cobra Supergroup in Western New South Wales, Australia)

- Drygant and Szaniawski (2012) (from Podolia, Ukraine)

- Corriga et al. (2014) (from Tafilalt, southeastern Morocco)

- Ziegler $(1975,1991)$

As such, the age of this biozones is Pridoli.

2. Eugenathodontidae-Icriodus assemblage zone

The elements collected in this part are related to Eugenathodontidae and include the followings genus:

- Bipennatus (Philip, 1965)

- B. bipennatus (Bischoff and Ziegler, 1957)

- B. bipennatus bipennatus (Bischoff and Ziegler, 1957)

- Icriodus sp.

- I. struvei (Weddige, 1977)

- I. brevis (Stauffer, 1940)

- I. brevis brevis (Stauffer, 1940)

- I. brevis spicatus (Youngquist and Peterson, 1947)

As such, the age of this biozone is Pragian to Emsian with the collected elements being comparable to those in the following work:

- Mathieson et al. (2016) (from Cobra Supergroup in Western New South Wales, Australia); Murphy (2005) (from Nevada)

- Murphy (2005) (from Nevada)

- Corriga et al. (2014) (from Podolia, Ukraine)

- Clark et al. (1966) (from Nevada)

- Nasehi (1996) (from Central Iran)

- Ziegler $(1975,1991)$

It is difficult to identify the contact between the Silurian and Devonian. The studied section exhibit a stratigraphic hiatus between the Late Pridoli and Early Pragian. Lochkovian deposits have not been observed in Iran; therefore, Central Iran was exposed out of water.

\section{Conclusion}

The studied section indicates that the Padeha Formation has two members across this area. The lower part (evaporative deposits with carbonate intercalations) has been aged back to the Late Silurian, while the upper part of Padeha Formation (clastic deposits 
with carbonate intercalations) is reported to be formed in the Early Devonian. The contact between the lower and upper parts exhibits a sedimentary hiatus (Late Pridoli to Late Emsian). Stratigraphists and geologists can correlate the stratigraphic column with this section. Using stratigraphic principles, it will be possible to solve the problem of age determination in Central Iran.

Within this time window, present-day Iran formed on the northern margin of the Gondwana Supercontinent, which later divided into separate structural units under the effect of Caledonian epirogenic movement (from faulting and formation of horst and graben basins). In the Late Silurian and Early Devonian, sea transgression and regression occurred, respectively. Note that the transgression at this time extended to limited parts of Iran. The evidence presented herein confirms the hypothesis of a horst and graben basin along the paleo faults in Central Iran in the Early Paleozoic.

\section{REFERENCES}

[1] Adhamian, A. (2003): Middle Devonian (Givetian) conodont biostratigraphy in the Soh area, north of Esfahan, Iran. - Courier Forschungsinstitut Senckenberg 245:183-193.

[2] Ahmadi,T., Dastanpour,M., Vaziri, M. (2012): Upper Frasnian(upper Devonian) Polygnathus and Icridus conodonts from the Bahram formation, Hur section, Kerman province, Southeastern Iran. - Rivista Italiana di Paleontologia e Stratigrafia 118(2):203213.

[3] Alavi, M. (1991): Tectonic Map of the Middle East. - Geological Survey of Iran. 60 pp.

[4] Alavi-Naini, M., Bolourchi, M.H. (1973): Explanatory Text of the Maku Quadrangle Map. - Geological Survey of Iran. A1 44P.

[5] Ashouri, A.R. (2004): Late Devonian and Middle-Late Devonian conodonts from eastern and northern Iran. - Revista Espaňola Micropaleontologia 3: 355-365.

[6] Ashouri, A.R. (2006): Middle Devonian-Early Carboniferous conodont faunas from the Khoshyeilagh Formation, Alborz Mountains, north Iran. - Journal of Sciences 17: 53-65.

[7] Assereto, R. (1963): The Paleozoic formations in central Elburz (Iran). - Rivista Italiana di Paleontologia e Stratigrafia 69:503-543.

[8] Bahrami, A., Corradini, C., Over, D. J., Yazdi, M. (2013): Conodont biostratigraphy of the upper Frasnian-lower Famennian transitional deposits in the Shotori Range, Tabas area, Central-East Iran Microplate. - Bulletin of Geosciences 88(2):369-388.

[9] Bahrami, A., Corradini, C., Yazdi, M. ( 2011): Upper Devonian-Lower Carboniferous conodont biostratigraphy in the Shotori Range, Tabas area, Central-East Iran Microplate. - Bollettino della Società Paleontologica Italiana 50(1):35-53.

[10] Bahrami, A., Königshof, P., Boncheva, I., Tabatabaei, M.S., Yazdi, M., Safari, Z. (2015): Middle Devonian (Givetian) conodonts from the northern margin of Gondwana (Soh and Natanz regions, North-West Isfahan, Central Iran): biostratigraphy and palaeoenvironmental implications. - Palaeobiodiversity and Palaeoenvironments 95(4): 555-577.

[11] Bahrami, A., Zamani, F., Corradini, C., Yazdi, M., Ameri, H. (2014): Late Devonian (Frasnian) conodonts from the Bahram Formation in the Sar-e-Ashk Section, Kerman Province, Central-East Iran Microplate. - Bollettino della Società aleontologica Italiana 53(3): 179-188.

[12] Bassler, R. S. (1925): Classification and stratigraphic use of the conodonts. - Bulletin of the Geological Society of America 36:218-220.

[13] Bichoff, G., Ziegler, W. (1957): Die Condontenchronologie des Mittel - devons und des tiefsten Oberdevons. -Abh. Hess. Landesamt Bodenforsch. 22: 1-136, 16 text-figs., 5 tables, 21 pls.,Wiesbaden. 
[14] Boncheva, I., Bahrami, A., Yazdi, M., Toraby, H. (2007): Carboniferous Conodont biostratigraphy and Late Paleozoic Platform Evolution in South Central Iran (Asadabad Section in Ramsheh area - SE Isfahan). - Rivista Italiana di Paleontologia e Stratigrafia 113 (3): 329-356.

[15] Bozorgnia, F. (1973): Paleozoic foraminifera biostratigraphy of central and east Alborz Mountain, Iran. - National Iranian oil company, Tehran. Geological Laboratories, Publ. no. 4.

[16] Branson, E. B., Mehl, M. G. (1933): Conodonts from the Bainbridge Formation (Silurian) of Missouri. - University of Missouri Studies 8:39-52.

[17] Branson, E. B., Mehl, M. G. (1934): Condonts from the Bushberg Sandstone and equivalent formation of Missouri. - Univ. Missouri Stud. 8:265-299, pls. 22-24, Columbia/ Mo.

[18] Branson, E. B., Mehl, M. G. (1941): New and little known Carboniferous conodont genera. - Journal of Paleontology 15:97-106.

[19] Bultynck, P. (1970): Revision stratigraphique et paleontologyque (Brachiopodes et Condontes) de la cou type du Couvinien. -Mem. Inst. Geol. Univ. Louvain 26:1-152, 16 text-figs., 39 pls., Louvain.

[20] Clark, D. L., Ethington, R. L. (1966): Conodonts and biostratigraphy of the lower and middle Devonian of Nevada and Utah. - Journal of Paleontology 40(3): 659-689.

[21] Corradini, C., Corriga, M. G., Mannik, P., Schonlaub, H. P. (2014): Revised conodont stratigraphy of the Cellon section (Silurian, Carnic Alps). - Lethaia 48(1):56-71. DOI: 10.1111/let.12087.

[22] Corriga, M. G., Corradini, C., Pondrelli, C. M., Simonetto, L. (2011): Lochkovian (Lower Devonian) conodonts from Rio Malinfier section (Carnic Alps, Italy). - Gortania. Geologia, Paleontologia, Paletnologia 33: 31-38.

[23] Corriga, M. G., Corradini, C., Walliser, O. H. (2014): Upper Silurian and Lower Devonian conodonts from Tafilalt, southeastern Morocco. - Bulletin of Geosciences 89(1): 183200.

[24] Drygant, D., Szaniawski, H. (2012): Lochkovian conodonts from Podolia, Ukraine and their stratigraphic significance. - Acta Palaeontologica Polonica 57(4):833-861.

[25] Farrell, J. R. (2004): Silurian-Devonian conodonts from the Camelford Limestone, Wellington, New South Wales, Australia. - Journal of Paleontology 47(4): 937-982.

[26] Flugel, E. (2010): Microfacies of Carbonate Rocks, Analysis, Interpretation and Application. - Springer-Verlag, Berlin.

[27] Gholamalian, H. (2007): Conodont biostratigraphy of the Frasnian-Famennian boundary in the Esfahan and Tabas areas, central Iran. - Geol. Quart. 51:453-476.

[28] Gholamalian, H., Ghorbani, M., Sajadi, S. H. (2009): Famennian conodonts from KaleSardar section, Eastern Tabas, Central Iran. - Riv. Ital. Paleontol. Stratigr. 115:141-158.

[29] Gholamalian, H., Kebriaei, M. R. (2008): Late Devonian conodonts from the Hojedk section, Kerman Province, southeastern Iran. - Rivista Italiana di Paleontologia e Stratigraphia, Milan 114(2):171-181.

[30] Heydari, E., Arzani, N., Hassanzadeh, J. (2008): Mantle plume: the invisible serial killerapplication to the Permian-Triassic boundary mass extinction. - Palaeogeogr Palaeoclimatol Palaeoecol 264:147-162.

[31] Huckriede, R., Kursten, M., Venzlaff, H. (1962): Zur Geologie des gebietes Zwischen Kerman und Saghand(Iran). - Beih. Geol. Jb. 51:197 S., 10 Taf., Hannover

[32] Huddle, J. W. (1934): Condonts from the new Albany Shale of Indiana. -Bull. Amer. Paleont. 21 (72): 1-136, 3 text-figs., 12 pls., Ithaca/N. Y.

[33] Klapper, G. (1969): Lower Devonian conodont sequence, Royal Creek, Yukon, Territory, and Devon Island, Canada. - Journal of Paleontology 43(1):1-27.

[34] Mathieson, D., Mawson, R., Simpson, A. J., Talent, J. A. (2016): Late Silurian (Ludlow) and Early Devonian (Pragian) conodonts from the Cobar Supergroup, western New South Wales, Australia. - Bulletin of Geosciences 91(3):583-652. 
[35] Murphy, M. A. (2005): Pragian conodont zonal classification in Nevada, western North America. [Zonación de conodontos praguienses en Nevada, oeste de Norteamérica.] Revista Española de Paleontología 20(2): 177-206.

[36] Murphy, M. A., Valenzuela-Ríos, J. I., Carls, P. (2004): On classification of Pridoli (Silurian)-Lochkovian (Devonian) Spathognathodontidae (Conodonts). - University of California, Riverside, Campus Museum Contribution 6:1-25.

[37] Nasehi, E. (1996): Early to Middle Devonian conodont from central Iran. - Geo. Sci. Quart. 6(21-22): 78-87. (In Persian with English abstract).

[38] Philip, G. M. (1965): Lower Devonian conodonts from the Tyers area, Gippsland, Victoria. - Proceedings of the Royal Society of Victoria 79:95-117.

[39] Philip, G. M. (1966): Lower Devonian conodonts from the Buchan Group, eastern Victoria. - Micropaleontology 12:441-460.

[40] Rhodes, F. H. T. (1953): Some British Lower Paleozoic condont faunas. -Phil. Trans. Roy. Soc. London, ser. B, 237: 261-334, 20 text-figs., 4 tables, pls. 20-23, London.

[41] Rhodes, F. H. T., Muller, K. J. (1956): The condonts genus Prioniodus and related forms. - J. Paleont. 30: 695-699, 1 table, Tulsa/Okla.

[42] Ruttner, A., Nabavi, M., Hajian, J. (1968): Geology of the Shirgesht area (Tabas Area,East Iran). - Geol. Surv. Iran Rep. 4:1-133.

[43] Soffel, H. C., Forster, H. G. (1980): Apparent polar wander path of central Iran and its geotectonic interpretation. - J.Geomag. Geoelectr. 32(Suppl. II): 117-135.

[44] Stocklin, J. (1968): Structural history and tectonics of Iran: A review. - Amer. Assoc. Petrol. Geologists Bull. 52 (7). DOI: 10.1306/5D25C4A5-16C1-11D7$8645000102 \mathrm{C} 1865 \mathrm{D}$

[45] Stocklin, J., (1971): Stratigraphic Lexicon of Iran. Part 1: Central, North, and East Iran. Geological Survey of Iran, Reports 18:1-338.

[46] Stocklin, J., Eftekhar-Nezhad, J., Hushmand-Zadeh, A. (1965, reprinted 1991): Geology of the Shotori range (Tabas area, east Iran). - Geological Survey of Iran, Reports 3: 1-69.

[47] Stocklin, J., Nabavi, M. H. (1971): Explanatory text of the Boshruyeh Quadrangle map 1:250.000. - Geological Survey of Iran, Geological Quadrangle J7: 1-50.

[48] Stocklin, J., Setudehnia, A. (1991): Stratigraphic Lexicon of Iran. - Geological Survey of Iran, Reports 18: 1-376.

[49] Stuffer, C.R. (1940): Conodonts from the Devonian and associated clays of Minnesota. Journal of Paleontology 14:417-435.

[50] Sweet, W. C. (1988): The Conodonta Morphology, Taxonomy, Paleoecology and Evolutionary History of Long-Extinct Animal Phylum. - Oxford University Press, New York.

[51] Ulrich, E. O., Bassler, R. S. (1926): A classification of the toothlike fossils, condonts. Proc. U. S. Nat. Mus. 68, art. 12: 1-63, 4 text-figs., 11 pls., Washington/ D. C.

[52] Walliser, O. H. (1957): Conodonten aus dem oberen Gotlandium Deutschlands und der Karnischen Alpen. - Notizblatt des hessischen Landesamtes für Bodenforschung 85:2852. Pls 1-3. 3 figs.

[53] Walliser, O.H. (1964): Conodonten des Silurs. - Abhandlungen des Hessischen Landesamtes für Bodenforschung zu Wiesbaden 41:1-106.

[54] Weddige, K. (1984): Zur Stratigraphie und Paläogeographie des Devons und Karbons von N.E., Iran. - Senckenbergiana lethaea 65(1-3):179-223.

[55] Weddige, K. (1977): Die Conodonten der Eifel-Stufe im Typusgebiet und in benachbarten Faziesgebieten. - Senckenbergiana Lethaea 58(4-5): 271-419. 9 fig., 20 tab.6 pl., Frankfurt/Main.

[56] Yazdi, M. (1999): Late devonian-carboniferous conodonts from Eastern Iran. - Riv. Ital. Paleontol. Ratigr. 105:167-200.

[57] Youngquist, W., Peterson, R. F. (1947): Condonts from the Sheffield Formation of northcentral lowa. - J. Paleont. 14: 417-435, pls. 58-60, TTulsa/Okla. 
[58] Ziegler, W. (1956): Unterdevonischen Conodonten, insbesondere aus dem Schönauer und dem Zorgensis-Kalk. - Notizblatt des hessischen Landesamtes für Bodenforschung 84: 93-106.

[59] Ziegler, W. (1960): Condonten aus dem Rheinischen Unterdevon (Gedinnium) des Remscheider Sattels (Rheinisches Schiefergebirge). - Palaont. Z. 34:169-201, 2 text-figs., 3 tables, pls. 13-15, Stuttgart.

[60] Ziegler, W. (1966): Eine Verfeinerung der Condontengliederung an der Grenze Mittle/Oberdevon. - Fortschr. Geol. Rheinld. Westf. 9: 647-676, 4 text-figs., 5 tables, 6 pls., Krefeld.

[61] Ziegler, W. (ed.) (1975): Catalogue of conodonts II. 404 pp. - E. Schweizerbart'sche Verlagsbuchhandlung, Stuttgart.

[62] Ziegler, W. (ed.) (1991): Catalogue of Conodonts V. - E. Schweizerbart'sche Verlagsbuchhandlung, Stuttgart.

\section{APPENDIX}

Plate 1

1. Bipennatus Philip, 1965

2. B. bipennatus bipennatus Bischoff and Ziegler, 1957

3. B. bipennatus bipennatus Bischoff and Ziegler, 1957

4. B. bipennatus bipennatus Bischoff and Ziegler, 1957

5. B. bipennatus bipennatus Bischoff and Ziegler, 1957

6. Bipennatus bipennatus Bischoff and Ziegler, 1957

7. Bipennatus bipennatus Bischoff and Ziegler, 1957

8. Bipennatus bipennatus Bischoff and Ziegler, 1957

9. Bipennatus sp.aff B. palethorpei Telfond, 1975 (Plate 2: 4, 8)

10. Bipennatus Philip, 1965

11. Bipennatus Philip, 1965

12. Bipennatus bipennatus Bischoff and Ziegler, 1957

13. Bipennatus bipennatus Bischoff and Ziegler, 1957 


\section{Plate 1}

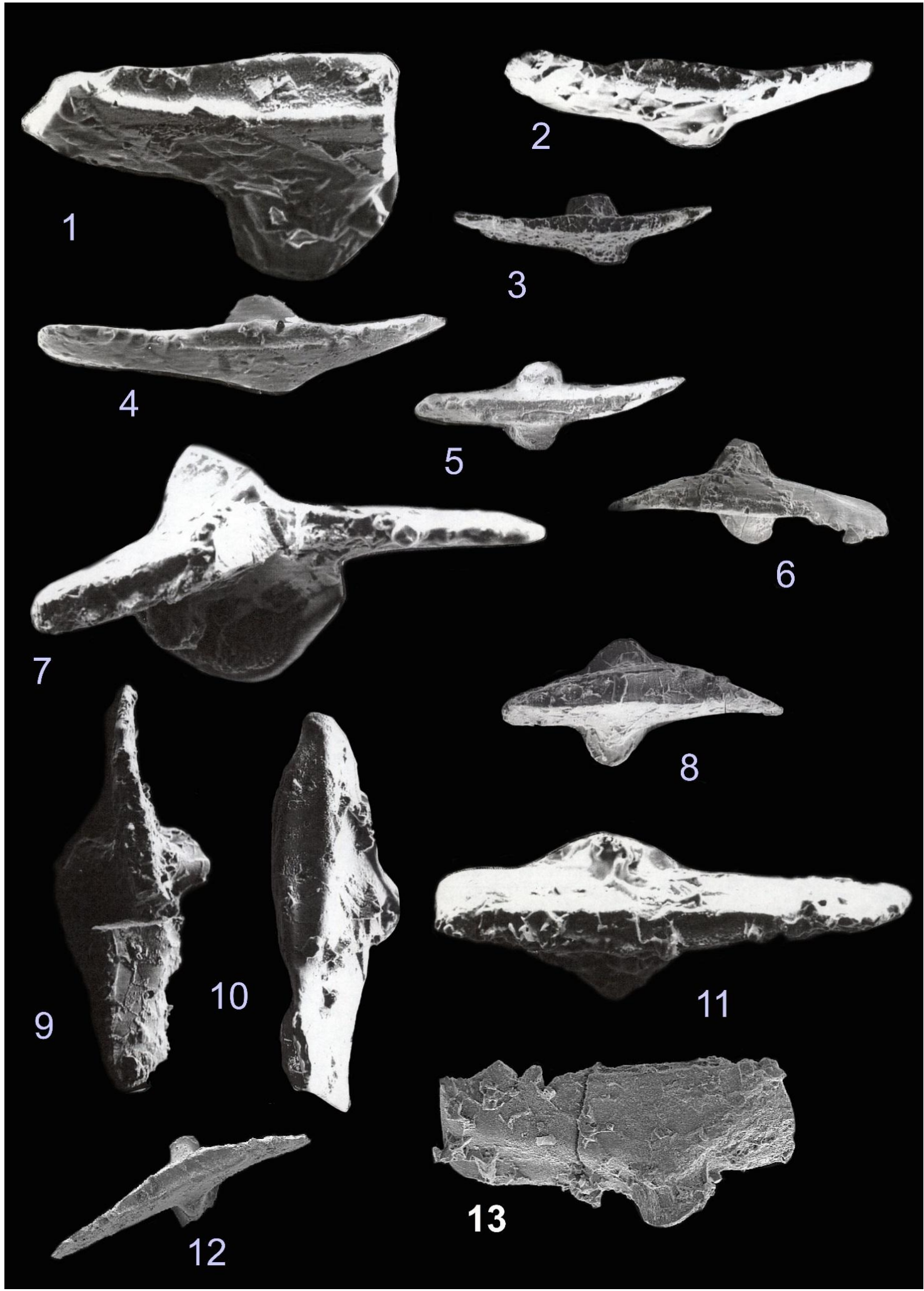




\section{Plate 2}

1. Ozarkodina ziegleri Walliser, 1964

2. Ozarkodina ziegleri Walliser, 1964

3. Trichonodella symetrica Branson and Mehl, 1933

4. Ozarkodina ziegleri Walliser, 1964

5. Ozarkodina ziegleri Walliser, 1964

6. Ozarkodina Branson and Mehl, 1933

7. Ozarkodina ziegleri Walliser, 1964

8. Trichonodella symetrica Branson and Mehl, 1933

9. Ozarkodina Branson and Mehl, 1933

10. Trichonodella symetrica Branson and Mehl, 1933

11. Trichonodella symetrica Branson and Mehl, 1933

12. Trichonodella symetrica Branson and Mehl, 1933

13. Trichonodella symetrica pinnula Philip, 1966

14. S element of ? Ozarkodina Branson and Mehl, 1933 


\section{Plate 2}

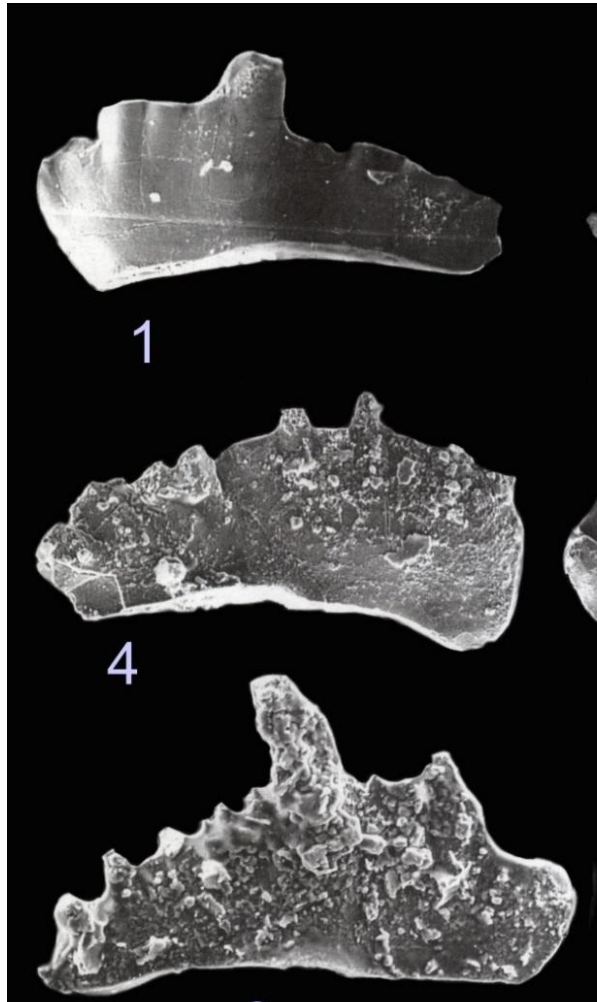

6

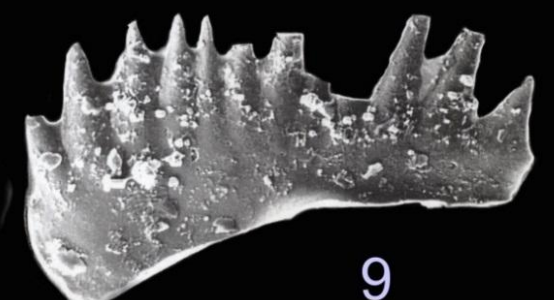

9
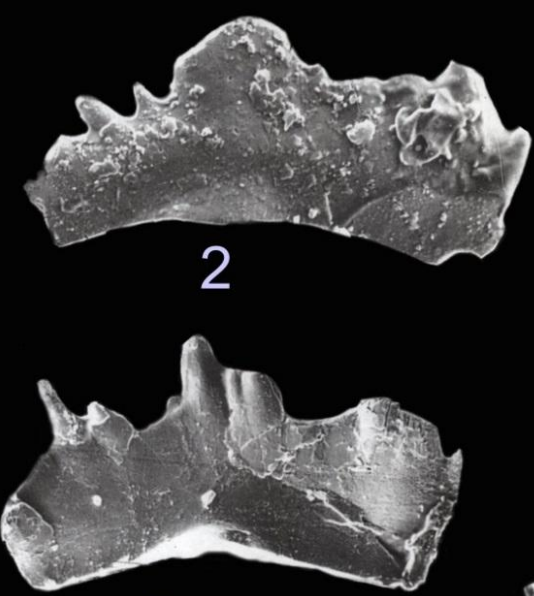

5

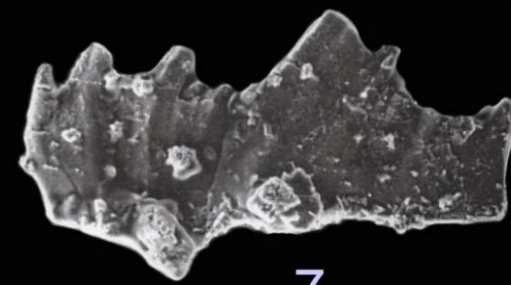

7
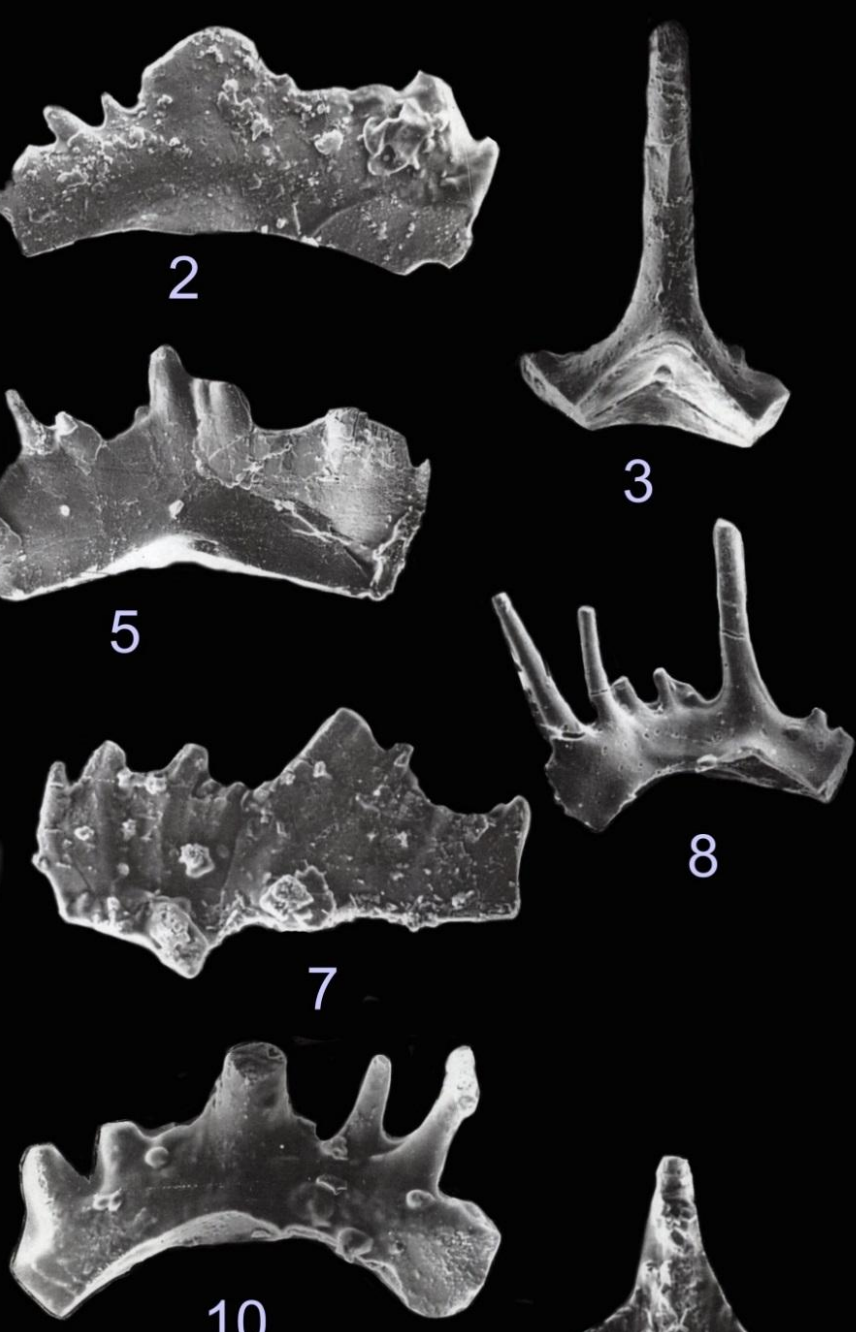

8

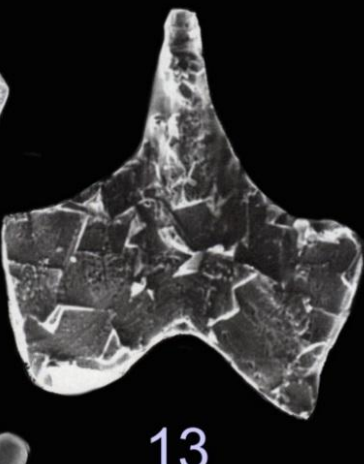

11

14 


\section{Plate 3}

1. Ligonodina elegans Walliser 1964

2. Ligonodina Bassler, 1925

3. Distomodus Branson and Mehl 1947

4. Lonchodina Bassler, 1925

5. Hindeodella equidentata Rhodes, 1953

6. Ozarkodina typica denckmanni Ziegler, 1956

7. Ozarkodina denckmanni Ziegler, 1956

8. Ozarkodina denckmanni Ziegler, 1956

9. Lonchodina Bassler, 1925

10. Ozarkodina typica denckmanni Ziegler, 1956

11. Ozarkodina typica denckmanni Ziegler, 1956

12. Ozarkodina typica denckmanni Ziegler, 1956

13. Ozarkodina typica denckmanni Ziegler, 1956

14. Ozarkodina ziegleri Walliser, 1964

15. Ozarkodina typica denckmanni Ziegler, 1956

16. Ozarkodina typica denckmanni Ziegler, 1956 


\section{Plate 3}

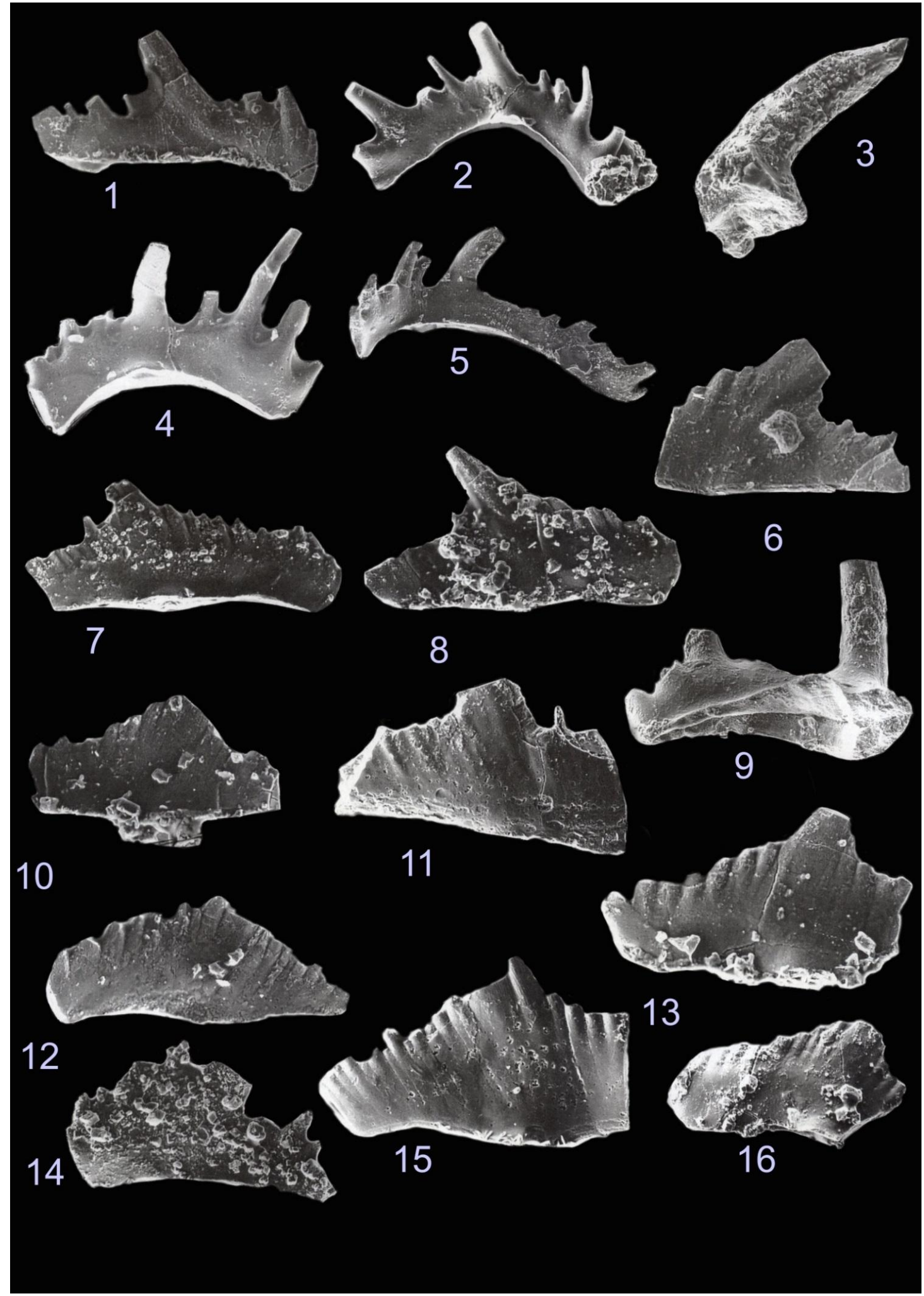




\section{Plate 4}

1. Hindeodella subtillis N166

2. Hindeodella equidentata Rhodes, 1953 N22

3. Wurmiella excavata Branson and Mehl, 1933; Neopripniodus excavatus Branson and Mehl, 1933 N30

4. Lonchodina Bassler, 1925 N20

5. Ligonodina salopina Rhodes, 1953, N24

6. Ligonodina salopina Rhodes, 1953, N25

7. Neopripniodus bicurvatus Branson and Mehl, 1933 N30

8. Wurmiella excavata Branson and Mehl, 1933 Neopripniodus excavatus (Branson and Mehl)

9. Wurmiella excavata Branson and Mehl, 1933 Neopripniodus excavatus (Branson and Mehl) N

10. Neopripniodus bicurvatoides Walliser, 1964 N30

11. Lonchodina Bassler, $1925 \mathrm{~N} 21$

12. Wurmiella excavata Branson and Mehl, 1933; Neopripniodus excavatus (Branson and Mehl) N20

13. Lonchodina Bassler, 1925 N20

14. Lonchodina Bassler, $1925 \mathrm{~N}$

15. Wurmiella excavata Branson and Mehl, 1933 Neopripniodus excavatus (Branson and Mehl) N20 


\section{Plate 4}

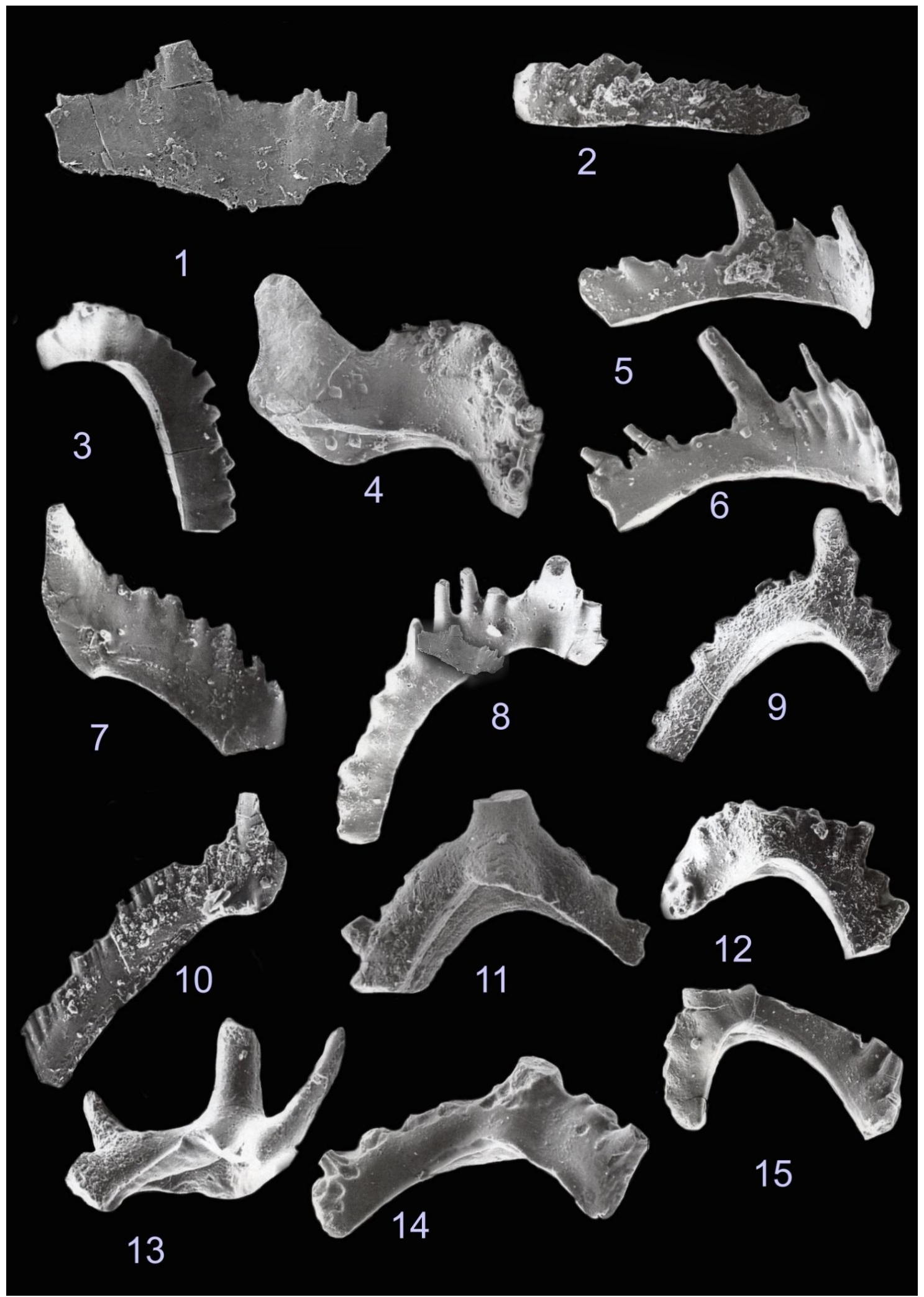




\section{Plate 5}

1. Ozarkodina confluens Branson and Mehl, 1933 (Spatognathodus primus primus Branson and Mehl, 1933) N21

2. Ozarkodina confluens Branson and Mehl, 1933 (Spatognathodus primus primus Branson and Mehl, N19

3. Zieglerodina remscheidensis Ziegler, 1960 (Spathognathodus remscheidensis Ziegler,1960) N 22

4. Zieglerodina remscheidensis Ziegler, 1960 (Spathognathodus remscheidensis Ziegler, 1960) N25

5. Zieglerodina remscheidensis Ziegler, 1960 (Spathognathodus remscheidensis Ziegler, 1960) N19

6. Zieglerodina remscheidensis Ziegler, 1960 (Spathognathodus remscheidensis Ziegler, 1960) N25

7. Ozarkodina confluens Branson and Mehl, 1933 (Spatognathodus primus Branson and Mehl, 1933) N19

8. Ozarkodina confluens Branson and Mehl, 1933 (Spatognathodus primus Branson and Mehl, 1933) N24

9. Pandorinellina exigua Philip, 1966 (Spathognathodus exiguous Philip, 1966) $\mathrm{N} 21$

10. Pandorinellina exigua Philip, 1966 (Spathognathodus exiguous Philip, 1966) $\mathrm{N} 21$

11. Pandorinellina exigua Philip, 1966 (Spathognathodus exiguous Philip, 1966) $\mathrm{N} 22$

12. Pandorinellina exigua Philip, 1966 (Spathognathodus exiguous Philip, 1966) $\mathrm{N} 21$

13. Pandorinellina exigua Philip, 1966 (Spathognathodus exiguous Philip, 1966) $\mathrm{N} 20$

14. Zieglerodina remscheidensis Ziegler, 1960 (Spathognathodus remscheidensis Ziegler, 1960) N19

15. Pandorinellina exigua Philip, 1966 (Spathognathodus exiguous Philip, 1966) $\mathrm{N} 21$

16. Pandorinellina of exigua Philip, 1966 (Spathognathodus exiguous Philip, 1966) N19

17. Pandorinellina sp Muller \& Muller 1957

18. Pandorinellina steinhornensis Ziegler, 1966 (Spathognathodus steinhornensis Ziegler, 1956) N23

19. Ozarkodina of confluens Branson and Mehl, 1933 (Spatognathodus primus Branson and Mehl, 1933) N25

20. Zieglerodina cf remscheidensis Ziegler, 1960 (Spathognathodus remscheidensis Ziegler, 1960) N21

21. Pandorinellina cf steinhornensis Ziegler, 1966 (Spathognathodus steinhornensis Ziegler, 1956) N19 


\section{Plate 5}
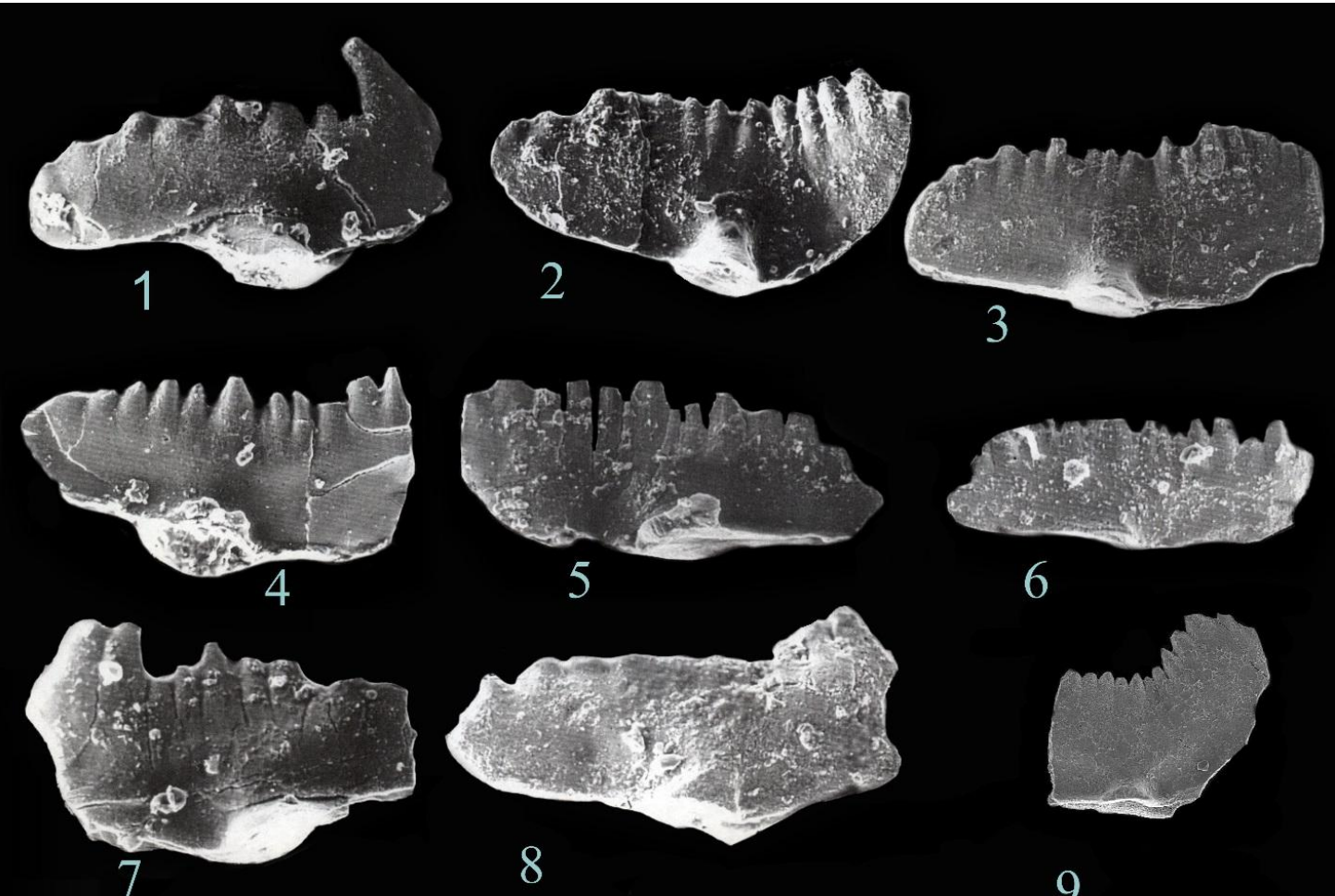

6
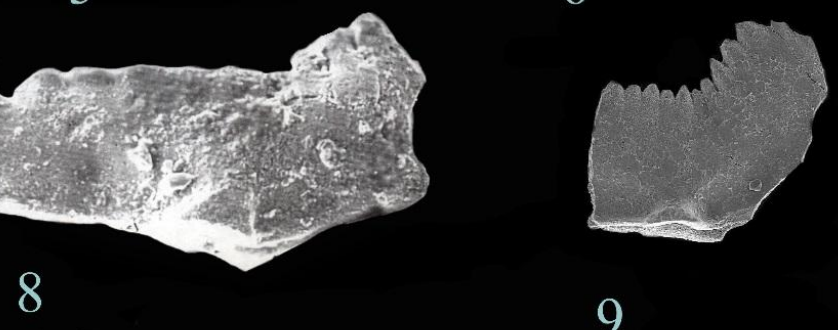

8

9
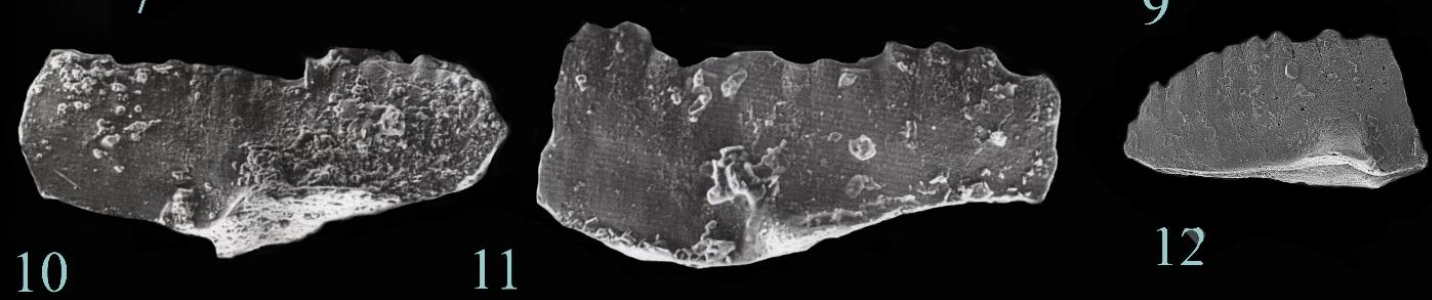

12

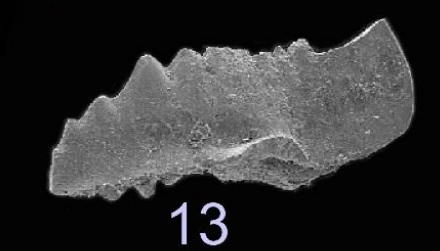

11
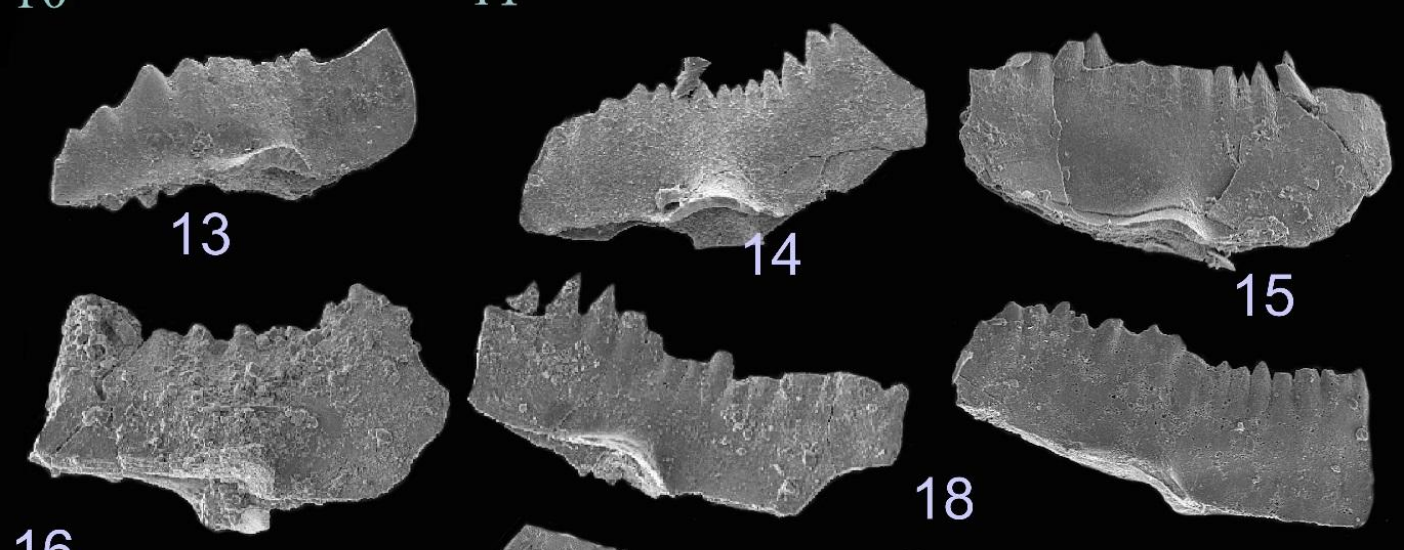

16

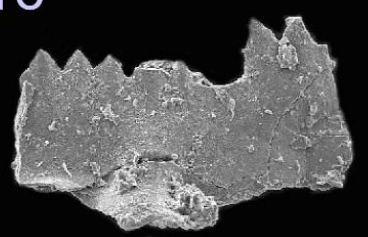

19
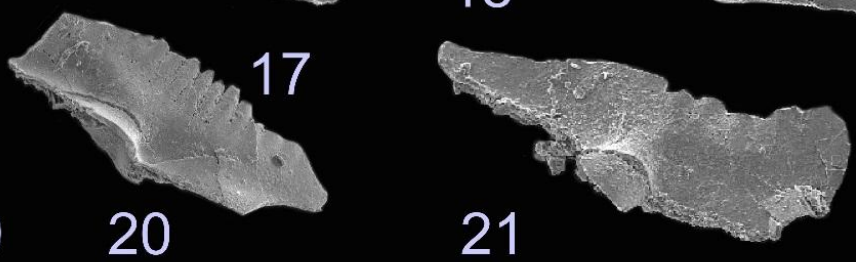


\section{Plate 6}

1. Zieglerodina remscheidensis Ziegler, 1960 (Spathognathodus remscheidensis Ziegler, 1960) N26

2. Ozarkodina confluens Branson and Mehl, 1933 (Spatognathodus primus Branson and Mehl, 1933) N25

3. ?Pandorinellina exigua Philip, 1966 (Spathognathodus exiguous Philip, 1966)

4. Zieglerodina remscheidensis Ziegler, 1960 (Spathognathodus remscheidensis Ziegler, 1960) N24

5. Ozarkodina confluens Branson and Mehl, 1933 (Spatognathodus primus primus Branson and Mehl, 1933) N26

6. Pandorinellina steinhornensis Ziegler, 1966 (Spathognathodus steinhornensis Ziegler, 1956) N18

7. Pandorinellina steinhornensis Ziegler, 1966 (Spathognathodus steinhornensis Ziegler, 1956) N24

8. Ozarkodina confluens Branson and Mehl, 1933 (Spatognathodus primus primus Branson and Mehl, 1933) N20

9. Zieglerodina remscheidensis Ziegler, 1960 (Spathognathodus remscheidensis Ziegler, 1960)

10. Pandorinellina steinhornensis Ziegler, 1966 (Spathognathodus steinhornensis, Ziegler, 1956) N20

11. Pandorinellina exigua Philip, 1966 (Spathognathodus exiguous Philip, 1966) $\mathrm{N} 22$

12. Pandorinellina exigua Philip, 1966 (Spathognathodus exiguous Philip, 1966) $\mathrm{N} 22$

13. Pandorinellina steinhornensis Ziegler, 1966 (Spathognathodus steinhornensis Ziegler, 1956) N26

14. Pandorinellina exigua Philip, 1966 (Spathognathodus exiguous Philip, 1966) $\mathrm{N} 20$

15. Pandorinellina exigua Philip, 1966 (Spathognathodus exiguous Philip, 1966) $\mathrm{N} 22$

16. Pandorinellina steinhornensis Ziegler, 1966 (Spathognathodus steinhornensis Ziegler, 1956) N19

17. Pandorinellina steinhornensis Ziegler, 1966 (Spathognathodus steinhornensis Ziegler, 1956)N26

18. Ozarkodina confluens Branson and Mehl, 1933 (Spatognathodus primus Branson and Mehl, 1933) N19

19. Pandorinellina exigua Philip, 1966 (Spathognathodus exiguous Philip, 1966) $\mathrm{N} 20$

20. Pandorinellina steinhornensis Ziegler, 1966 (Spathognathodus steinhornensis Ziegler, 1956) N21

21. Ozarkodina confluens Branson and Mehl, 1933 (Spatognathodus primus Branson and Mehl, 1933) N24

22. Pandorinellina steinhornensis Ziegler, 1966 (Spathognathodus steinhornensis Ziegler, 1956) N19 


\section{Plate 6}

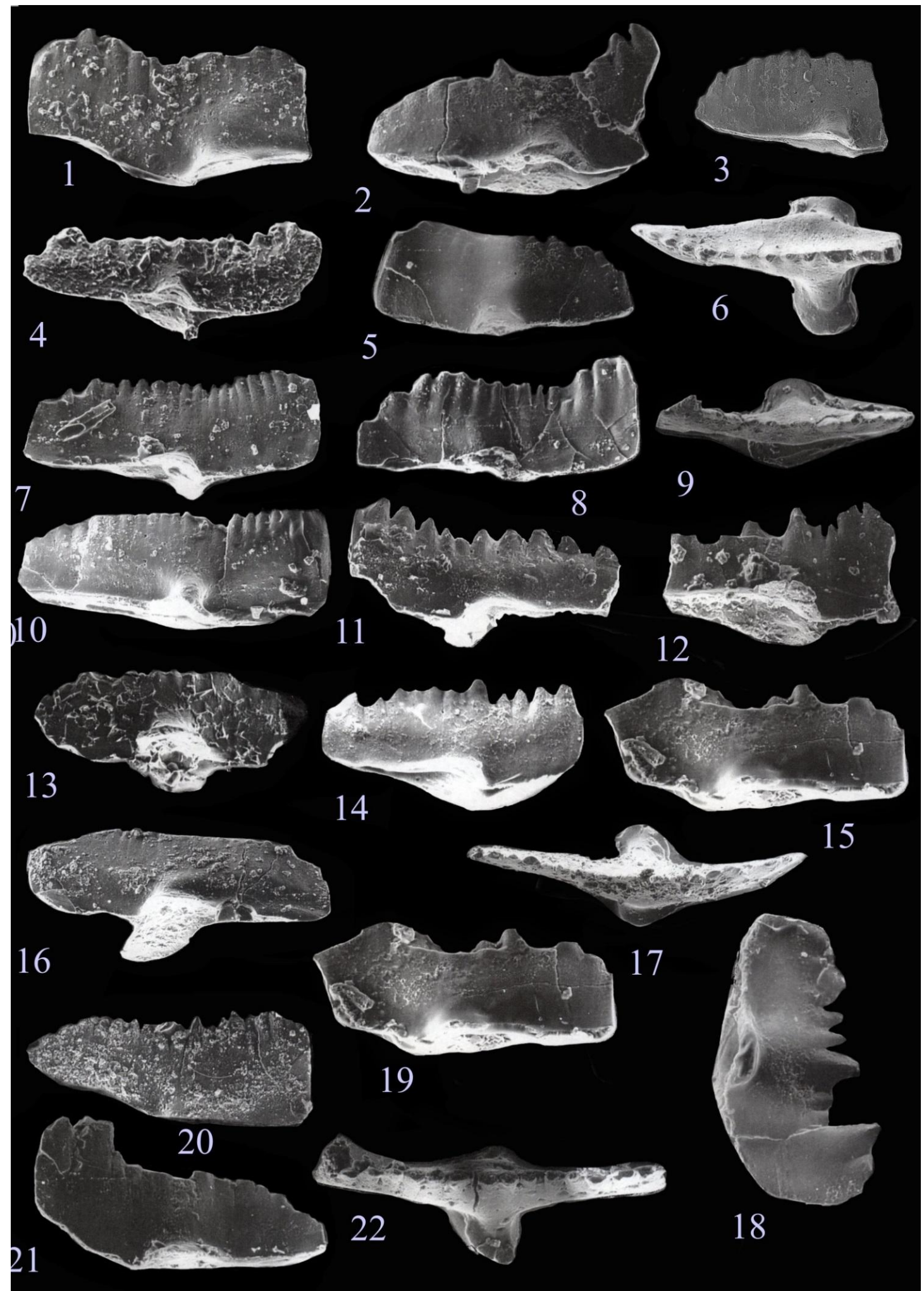




\section{Plate 7}

1. Icriodus brivis spicatus Youngquist and Peterson, 1947 no. 65

2. Icriodus brevis brevis Stauffer, 1940

3. Icriodus regularicresens Bultynck, 1970

4. Icriodus regularicresens Bultynck, 1970

5. Icriodus sp Branson and Mehl, 1934

6. Icriodus regularicresens Bultynck, 1970

7. Icriodus regularicresens Bultynck, 1970

8. Icriodus struvei Weddige, 1977

9. Icriodus.regularicresens Bultynck, 1970

10. Icriodus struvei Weddige, 1977

11. Icriodus regularicresens Bultynck, 1970

12. Icriodus struvei Weddige, 1977

13. Icriodus regularicresens Bultynck, 1970

14. Icriodus $\mathrm{sp}$

15. Icriodus brivis spicatus Youngquist and Peterson, 1947

16. Icriodu brivis spicatus Youngquist and Peterson, 1947 
Plate 7

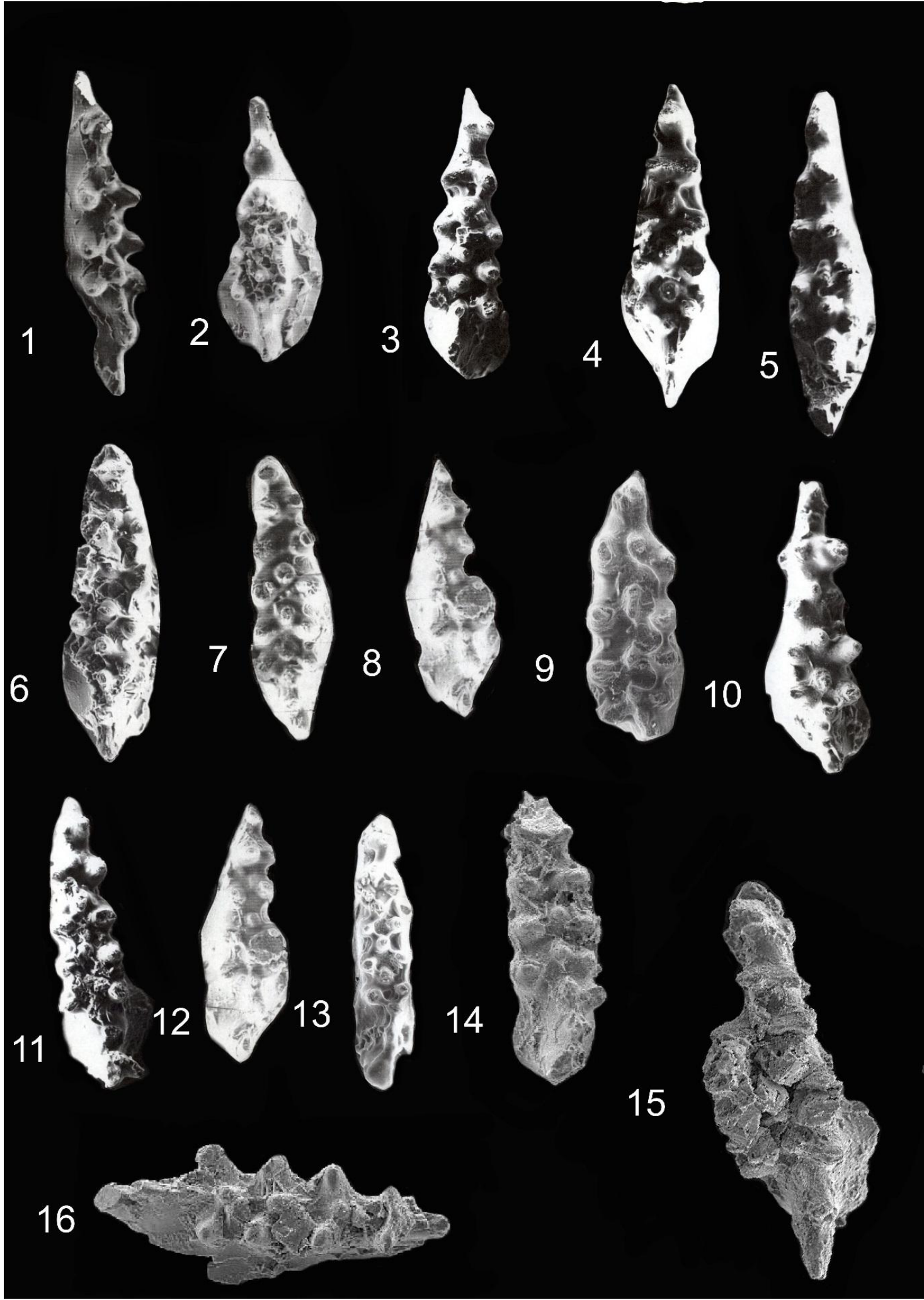

